\title{
Performance and profit sensitivity to risk: a practical evaluation of the agro-industrial projects developed by Israeli companies for the $\mathrm{CIS}$ and Eastern European countries
}

Gregory Yom Din ${ }^{1,2}$

\section{Correspondence:}

gregoryyd@gmail.com

'Department of Management and Economics, the Open University of Israel, Raanana, Israel

${ }^{2}$ Faculty of Exact Sciences, Tel-Aviv

University, Tel-Aviv, Israel

\begin{abstract}
International companies take part in many tenders for agro-industrial projects in the Commonwealth of Independent States and Eastern European countries. The market for these projects is analyzed and found to be favorable for companies and developers. Major projects developed in recent years are presented and evaluated in terms of financial performance. Additionally, a method of project evaluation by profit sensitivity to risk criterion is proposed. In this method, the approximate formula for profit sensitivity to risk (when basic production and market assumptions change simultaneously) is derived using a cost-volume-profit model. This method allows minimal calculations to explain profit sensitivity and elasticity within the usual indicators of business planning: operational profitability and degree of operating leverage. The consistency of project ranking is examined using Cronbach's alpha and correlation coefficients. The ranks obtained by various performance criteria are found to be consistent with each other, but not with those obtained by profit sensitivity to risk. In terms of elasticity, project profitability is a much stronger influence than the degree of operating leverage on profit sensitivity to risk.
\end{abstract}

\section{Background}

Many Commonwealth of Independent States (CIS) and Eastern European (EE) countries have enjoyed a period of rapid economic growth since the beginning of 2000's, except for the 2008-2010 period of financial crisis. During 2000-10, investment in fixed assets in CIS countries increased by 150 percent in terms of real prices, in Romania by $122 \%$ and in Bulgaria by $66 \%$. In comparison, fixed asset investment in EU-27 countries averaged an $18 \%$ increase over the same period. In Russia, this investment reached US \$290 billion, with the agro-industrial sector accounting for $4 \%$. Over 2008-11, the annual investment in Russian agriculture was about US \$12 billion, in Ukraine \$2 billion, in Belarus \$2 billion, in Kazakhstan \$620 million and in Romania \$940 million (in 2009) (RosStat 2012, UkrStat 2012, BelStat 2012, KazStat 2012, Romania Stat 2012, EuroStat 2012b).

Many international companies compete in this market and submit projects for potential implementation. In Russian agriculture, international and joint domestic-international

(c) 2013 Yom Din; licensee Springer. This is an Open Access article distributed under the terms of the Creative Commons Attribution License (http://creativecommons.org/licenses/by/2.0), which permits unrestricted use, distribution, and reproduction in any medium, provided the original work is properly cited. 
companies accounted for 6.5\% of investments over 2009-10 (RosStat 2012). Every year, Israeli companies are involved in dozens of tenders for agro-industrial projects in various CIS and EE countries for the industries of poultry, dairy and pork production, fish farming, vegetable greenhouses, orchards, fruit packing houses and oilseed products. In order to win tenders, companies invest heavily in the development of economic models and business plans in accordance with accepted criteria, government guidelines and banking standards.

The objectives of this study are three-fold:

a) To describe the market situation for agro-industrial projects in the studied countries from the viewpoint of project developers.

b) To propose a method of project evaluation using profit sensitivity to risk analysis, in conjunction with evaluation by financial performance criteria.

c) To evaluate agro-industrial projects developed in Israel according to these criteria, and to analyze ranking consistency by different criteria.

A number of studies evaluating agricultural profitability in CIS and EE countries have been published in recent years. In the 1990's, most Russian companies considered the agricultural sector to be unprofitable and interest from foreign investors was limited. During this period, the Russian government sharply curtailed investment in the agricultural sector and large farm enterprises faced severe financial difficulties (Visser et al. 2012). Voigt and Hockmann (2008) found that from 1993-2003, there was little evidence documenting sustainable growth in Russian agriculture, and no significant transition progress was revealed. Agricultural production was rather industrialized but operated with decreasing returns to scale.

After 1991, agricultural systems in CIS and EE countries underwent major institutional changes. In the largest countries - Russia, Ukraine, and Kazakhstan - 23 million hectares of arable land was excluded from production by the mid-2000's (Lioubimtseva and Henebry 2012). These losses in production capacity were not accompanied by an adequate improvement in management and technology.

Liefert and Liefert (2012) addressed issues of agricultural productivity in Russia, Ukraine and Kazakhstan in this period of economic transition, and studied the effects of modern technology and management techniques on improving agricultural productivity and maximizing profits. They found that the majority of large agricultural enterprises remained technologically backward and chronically unprofitable, despite their industrial nature and vertical integration. Nevertheless, these large agricultural holdings played a large part in production for the large CIS countries in the end of 2000's. They were responsible for approximately $15 \%$ of total agricultural production in Russia, accounted for $66 \%$ of Kazakh grain marketed domestically and abroad, and cultivated $10 \%$ of the total farmland in Ukraine (Wandel et al. 2011).

Welfare of small farmers in many CIS and EE countries depended mostly on the market price for their output in environments where agricultural policy provided minimal support. These farmers could suffer from price heterogeneity even after controlling for product heterogeneity, as it is shown by Sauer et al. (2012) in analyzing the dairy sector of Armenia, Moldova and Ukraine. Voicilas (2011) cites high risk, weak profitability and institutional failures (slow pace of privatization, negligible reforms and high taxation) as 
the main reasons for the minimal place of Romanian agriculture in foreign direct investment. In 2008, only $1 \%$ of foreign investment was in agriculture, although that sector employed $30 \%$ of the total workers in the country.

In the literature on project evaluation, the choice of modeling tools and criteria has an important place. Production scheduling, sales planning, and cash budgeting are integrated in spreadsheet models through linking procedures, allowing for the development of an effective business plan (Chien and Cunningham 2000). For industrial agricultural projects, the dynamics of the growing process in crop industries and of herd/flock movement can be entered into a bio-economic model spreadsheet, in which the output of the biological and production processing modules serves as an input to an economic (cash flow) module.

Bio-economic framework developed as an Excel-based representation allowed for an evaluation of profit and resource management at a project/farm business level (Zhang and Wilhelm 2011, Kuehne et al. 2012). The problem of criteria in project evaluation was studied by Parfenova (2009) who discussed socio-economic criteria for industrial agricultural projects aimed at regional economic growth and improving general living standards. Mansurov (2011) proposed different criteria for competitive evaluation of industrial agricultural companies by decision-makers such as project initiators, business owners and government organizations. The latter are particularly interested in increased tax revenue and in tools for solving social problems. The methodological aspects of project evaluation, particularly the determination of the discount rate for cash flows, was analyzed by Bevzelyuk (2008).

Many of these studies incorporate the issue of risk in project evaluation. Strashko (2010) analyzed issues of business planning in relation to agro-industrial projects, specifically the need for risk, technical and financial analysis during the project evaluation. Hockmann et al. (2011) studied the influence of risk, expressed as variation in production and prices, on agricultural development and production growth in one of the regions of central Russia. The dual nature of risk in agriculture that follows from output and price uncertainty was analyzed by Ben-Zion et al. (2005), in the context of analyzing the difficulty in hedging agricultural production. On the other side, large-scale agro-industrial projects allow for export diversification in CIS countries, by replacing raw materials (mainly grain) with finished products. This enables the reduction of risk introduced by price volatility in the world market (Shepotylo 2012; Ksenofontov et al. 2012).

This brief review highlights the importance and specific details used for evaluating agro-industrial sector investment projects in the studied countries - the role of social factors, participation of multiple decision-makers, and exposure to multiple risk factors. However, practical examination of various evaluation methods for agro-industrial projects is not thoroughly presented in current economic literature. In particular, it is of great interest to compare result consistency of evaluations performed with different criteria and methods. Such examination is important, both for project developers and for customers interested in seeing multi-criteria investment project evaluation. In Russia, for example, with its technological and economic stratification in the agricultural sector, there are no mechanisms for harmonizing the interests of key decision-makers in regards to the evaluation of projected agribusiness projects and their solvency (Zaharov 2006; Kalugina 2011; Vasina 2012). 
The results of this study are based on data collected by the author in the course of more than fifteen years of work for Israeli companies on economic modeling and business planning for agro-industrial projects.

\section{The market situation for agro-industrial projects Food demand and production}

In the last decade, agricultural production in major CIS countries has increased significantly. From 2007-10, as compared to the period of 2003-06, the Food Production Index grew in these countries at a rate of $2.4-5.3 \%$ per year. In other countries in the region there was a mixed trend. In the Baltics, Estonia saw a decrease in production $(-1.8 \%)$ while significant increases were shown in Latvia (5.6\%) and Lithuania (3.2\%). In many EE countries, the average annual growth rate was negligible, such as in Bulgaria (1.2\%), or even negative, as for example in Romania (-1.6\%). In Israel, the average annual growth rate was negative at $-0.5 \%$ (Figure 1) (Commodity Markets 2012).

Many studies suggest that by 2050, the worldwide demand for food will have increased by some 70-100\% (Wise and Murphy 2012). In line with this outlook, and according to the more attractive features of agro-industrial export as opposed to traditional agricultural products (Torok and Jambor 2012), the amount of agro-industrial projects will undoubtedly increase in the countries studied. They have the necessary production potential for this to take place. In the three largest CIS countries - Russia, Ukraine and Kazakhstan - the potential for wheat production, evaluated on the basis of current yield totals, is about 99 million tons per year, which exceeds the current total production of wheat in the United States and Canada combined (based on data from Petrick et al. 2012). Agricultural exports to the European Union increased from 2003-07: from Russia by $24 \%$; from Ukraine by $77 \%$; from Kazakhstan by $102 \%$; from Belarus by

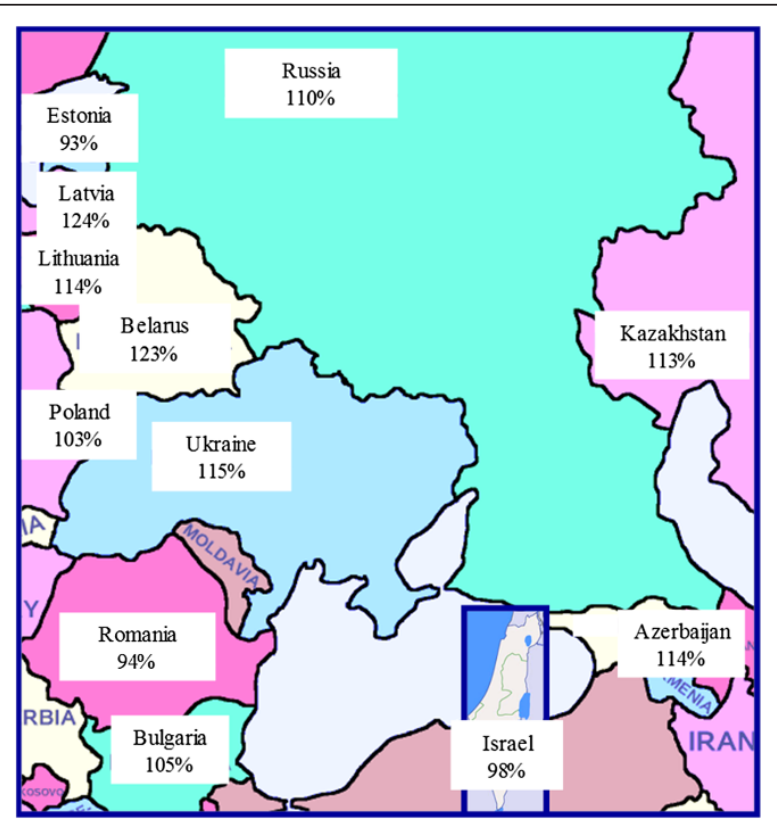

Figure 1 Growth of food production in 2007-10 compared to 2003-06. The assessment is based on the World Bank data (Commodity Markets, 2012). 
$10 \%$, from Romania by $51 \%$, and from Bulgaria by $40 \%$. The total annual value of agricultural exports from CIS countries to the EU reached US $\$ 7.8$ billion in 2012, with Russia accounting for almost half (based on data from Bojnec and Fertő 2012).

\section{Price growth}

In recent years, the global market for agricultural products has been characterized by a sharp rise in producer prices. The index of world prices for agricultural products grew during $2000-11$ by $7.1 \%$ per year (FAOSTAT 2012). Twice during this period, in 2008 and 2010, the index increased particularly sharply: by $19 \%$ and $16 \%$, respectively. This led to media reports of a world food crisis. In individual countries, prices also have risen sharply. For example from 2005-09 in Romania, the price index of basic agricultural products grew by $38 \%$ (Romania Stat 2012).

In 2011 the growth in world prices slowed, and the index rose by only 7\%. However, for many categories of food products that are relevant for CIS and EE countries, the price index has continued to grow rapidly. In 2011, the world price index for wheat in terms of producer prices increased by $33 \%$, for soybean oil by $29 \%$, and for beef by $21 \%$. Part of the growth in producer prices can be explained by increased prices for many resources important to agriculture - in 2011, energy prices rose by $19 \%$ and prices of chemical fertilizers by $43 \%$ (FAOSTAT 2012).

\section{Availability and affordability of food}

The industrial agriculture market is influenced by governmental commitment to food security. Current understanding of this problem was formulated by the 1996 Rome Declaration on World Food Security. In Russia, this term was defined in 2010 in the "Doctrine of Food Security," in Ukraine by a 2011 law, in Belarus by a 2004 government decision, and in Romania by the document "Strategies for Food Security," presented to the European Commission in 2001. The following characteristics of food security are defined in these documents: food quality, stable and sufficient production, and affordability for all residents.

The share spent on food from a household budget, as based on Engel's law, is one of the most important aspects in assessing standard of living. A decrease in food expense relative to total budget particularly indicates improved food affordability. In recent years, this index in Russia remained close to 30\%, similar to 1985 levels. In Ukraine in 2008 (a very unfavorable year economically) the index was even higher: 51\%. In 2010, Belarus and Kazakhstan saw household food budgets of $39 \%$ and $41 \%$, respectively. In 2005, the EE countries of Romania and Bulgaria had rates of $44 \%$ and 32\%, respectively, and the EU-27 had an average rate of 17\% (RosStat, UkrStat, BelStat, KazStat, Romania Stat 2012, EuroStat 2012a).

These estimations are in line with findings of other researchers. Otiman (2012) concluded that in Romania, the share of food expenses was between $40-45 \%$, a value twice as high as the EU-25 average and almost 2.8-3 times higher than the EU-15 average.

These data indicate that the relative cost of food in a household budget in the countries under consideration is $75-160 \%$ higher than the cost in EU countries, and thus affordability of food is much lower. 
The benefits and risks of agro-industrial projects

Modern technologies that are used in agro-industrial projects often belong to the field of agricultural biotechnology. This can be discerned in the areas of production, processing, storage, organization, and management. Long-term storage of fruit in controlled environment, sex changes of fish in aquaculture, protein production in soybean processing plants and extraction of industrial oils from biomass are all examples of this.

Products from agro-industrial projects are notable for their high, uniform quality and for their suitability for delivery to distant markets. Meat products from the poultry industry in Belarus is one example of this. Chicken pieces shipped in user-friendly, highquality packing have a third more value than a whole bird, and are delivered to major cities in Russia where prices are much higher as compared to Belarus (Table 1).

In new companies established for project implementation, food production is stable even in years of adverse weather conditions. For example, Russia in 2010 saw a 25\% decrease in general crop production because of low yields in many regions. At the same time, meat production increased by $6 \%$, because the industry is largely concentrated in industrial farms. In part, this increase can be explained due to feed shortage (based on data from RosStat 2012).

Many potential risks of industrial agricultural projects are derived from their high cost of implementation and profit volatility. Profitability is affected by inertia in international agricultural markets that are affected by trends of the previous year. Another feature that affects profitability is long production cycles and the initial period needed for raising a main herd, parent flock or fruit orchard. In the poultry sector, the period from the beginning of investment until the first revenues is at least 14 months, and in fruit orchards the period is 4 years, with another 2 years to reach full market yield. A similar long period is required to achieve full production from a new dairy farm.

Agro-industrial projects require initial investment and working capital relatively high as compared to traditional agricultural projects. Small-scale horticultural enterprises require US \$5-7 million, while large integrated poultry farms require investment of up to US \$50-90 million or more (Table 2). In CIS and EE countries, price volatility in the agricultural sector is much higher than yield volatility. From 2000-11 in Russia, the coefficient of variation, which measures the standard deviation as a part of the sample

Table 1 Wholesale prices of poultry meat products

\begin{tabular}{|c|c|c|c|}
\hline \multirow[t]{2}{*}{ Product } & & \multicolumn{2}{|c|}{ Prices*, US\$/Kr, and differences } \\
\hline & & Turkeys & Chicken \\
\hline \multicolumn{4}{|l|}{ Belarus } \\
\hline Whole bird & B1 & 4.67 & 2.06 \\
\hline Fillet & B2 & 6.51 & 2.81 \\
\hline Price difference & & $139 \%$ & $136 \%$ \\
\hline \multicolumn{4}{|l|}{ Russia } \\
\hline Whole bird & $\mathrm{R} 1$ & 5.75 & 2.67 \\
\hline Fillet & R2 & 7.78 & 4.48 \\
\hline Price difference & & $135 \%$ & $168 \%$ \\
\hline Difference between & $\mathrm{R} 1 / \mathrm{B} 1$ & $123 \%$ & $130 \%$ \\
\hline Countries & $\mathrm{R} 2 / \mathrm{B} 2$ & $120 \%$ & $159 \%$ \\
\hline
\end{tabular}

*The assessment is based on price proposals published from November 2011-January 2012. 
Table 2 General project characteristics

\begin{tabular}{llllr}
\hline No and year & Project & Country, region & Products & $\begin{array}{r}\text { Investment } \\
\text { 2012 US\$ million }\end{array}$ \\
\hline 12004 & Eggs & Russia, Central FD* & Eggs & 44 \\
22006 & Turkeys & Russia, Privolzhsky FD & Meat products & 86 \\
32009 & Fruit & Azerbaijan & Apple from storage & 5.3 \\
42009 & Vegetable greenhouses & Azerbaijan & Tomatoes & 7.0 \\
52009 & Broilers & Russia, Privolzhsky FD & Chickens & 80 \\
62009 & Broilers & Kazakhstan & Chickens & 53 \\
72010 & Eggs & Romania & Eggs & 27 \\
82010 & Orchard+ oil extraction & South-Eastern Europe & Technical oil & 1.5 \\
92011 & Pig farm & Belarus & Meat, meat products & 31 \\
102011 & Turkeys & Russia, Central FD & Meat, meat products & 110 \\
112011 & Turkeys & Belarus & Meat, meat products & 87 \\
122011 & Soy & Russia, Far East FD & Oil, soy proteins & 74 \\
132012 & Eggs & Belarus & Eggs, melange & 28 \\
142012 & Milk farm & Russia, North-West FD & Milk, cattle & 42 \\
\hline * FD - Federal district & & &
\end{tabular}

mean, was $16 \%$ for grain crops yield and $40 \%$ for the price of these crops (based on data from RosStat 2012).

Because of the mentioned factors, using profit sensitivity as a criterion of agroindustrial project analysis is justified. For the purposes of this article, risk is defined as simultaneous changes in several basic production and market factors that affect profitability and project investment.

\section{Institutional context in project choice and evaluation}

The institutional environment of the agricultural industry in the countries under consideration has changed decisively over the last decade. Below the most important changes in Russia are outlined; similar changes have taken place in other studied countries.

In 1992, Russia introduced a set of reforms aimed at building a market economy. The reformers predicted that the necessary institutions would come into being after private property was created (Goldman 2003). However, the results stemming from changes in land management were unexpected for the reformers. The absence of an adequate institutional environment led to a falloff in volume of agricultural production so drastic that the food security of the country came into question (Kalugina 2011).

After 2000, agricultural regulation and budgetary support was decentralized, and the center of gravity for agrarian policy was shifted from the central government to the regions (Saubanov 2010). The emergence of bank-issued credit served as an important engine for economic growth, and it spread from the Moscow district to other Russian regions (Berkowitz and DeJong 2011). These institutional changes led to a major transformation in the agro-industrial sector: private land ownership on a large scale, increased ability for producers to respond to market conditions and demand, creation of functioning wholesale markets for raw materials and 
agricultural products, an increased number of large integrated farms, and additional entrepreneurship opportunities. Investment environment in the agro-industrial sector were improved due to state support of investments in transportation infrastructure, cold storage, distribution, access to foreign markets for equipment and genetic material, interest rate subsidies, tax benefits, and customs preferences.

In Russia, further expansion of the state support in the development of agriculture and regulation of agricultural commodities markets is planned for 2013-2020 (The State Program for Development of Agriculture and Regulation of Agricultural Commodities Markets in 2013-2020 2012). The budget of the program accounts for about 16 US\$ billion divided by industries of crop and livestock sectors, land improvement, innovation, support in small farms, and social development of rural areas. The wide public support reduces the overall level of risk for the new projects.

These changes contribute to the development of the industrial agricultural sector. In 2010-11 in Russia, 70\% of agricultural land that was in use was under private ownership (Wegren 2012). Every month, more than 500 new companies register in the agricultural sector (RosStat 2012, including hunting and forestry enterprises). In 2009, total investment credit given by the Russian foreign trade and investment bank stood at US $\$ 7.7$ billion, with 25\% going to agro-industrial projects (Isakov 2011).

The following actors are central in evaluating agro-industrial projects, and in the decision to grant them subsidies and benefits:

a) The region, including the governor and the relevant departments of the regional government;

b) The bank, which participates in project financing and has experts who influence decisions;

c) The initiator of the project, whose interests usually coincide with those of the future owners of the new company, which will be established during project implementation.

These actors examine the project business plan and other relevant documents and perform due diligence by analyzing economic performance and investment risks. The region often seeks the opinion of academic institutions, the bank has internal experts to examine a business plan, and the initiator tends to seek the services of a reputable consulting firm.

Criteria for the region when deciding whether to support a project are often based on projected profitability for the new company - the budget effect of additional taxes for the region - and on the opportunity to obtain additional financing from the central government to invest in infrastructure supporting a profitable project. Social concerns are also important for the region, such as food security issues, employment opportunities, and new positions for workers with professional education. Besides providing administrative support, the region can decide on a substantial reduction in asset tax (ranging from $2.2 \%$ to $0.5 \%$ ). In some countries, the region can subsidize interest rates.

The bank uses the same performance criteria as the region. In addition, the bank is particularly attentive to analysis of profit sensitivity from project assumptions. This gives information about loan risk. Through the bank, a state interest rate subsidy can be implemented - in some cases, $75 \%$ and more of the interest can be returned to the 
new company. Based on the project's financial forecast, the bank can grant a 2-3 years grace period before for principal loan repayment begins.

The initiator pays relatively more attention to criteria based on discounted cash flow, especially the IRR. This performance measure allows for comparison between various project proposals. An additional concern is the ability to profit from vertical integration if a new project can use agricultural raw materials produced from enterprises already owned by the initiator. The initiator is responsible for mobilizing equity - usually, 20-25\% of investment cost. Examples of how much the initiator can be motivated in his decisions on choosing an agricultural project and in the production of specific agricultural products in the last decade are as follows: Reduced single taxes for agricultural producers to 6\% in Russia and 1\% in Belarus. Subsidy for specific products can play a part: in Russia, a state subsidy for the high quality milk can reach $25 \%$ of the milk farm gate price, and in Romania, an egg farm is granted 2.5 euro per layer per annum.

\section{Methods}

Data

The project evaluation data were collected and evaluated as follows:

- Technological data related to the production processes were provided by the Israeli companies that developed the projects, and by the suppliers of genetic material, equipment, and construction material. Local specialists were consulted regarding the possible impact of agro-climatic conditions on the projected technological data, e.g. soybean humidity, seasonal variation in egg lay rate, or feed nutritional value.

- Costs of labor, raw materials, energy, and services were collected from local statistics reports and annual reports of corporate customers. Labor costs, direct and indirect, included wages, state benefit fund payments and insurance. For each category of employees, their wages were projected $20-50 \%$ higher than the regional average. Feed costs were estimated using regional prices of fodder and feed additives and recommended optimal rations for different animal groups.

- Producer prices of products were estimated from data acquired from central statistical services, reports of various ministries of agriculture, and letters of intent from trade organizations and processing plants. Conservative price estimates (1-2 years average) were used, differentiated by region, season, and production quality.

- Construction costs were estimated based on tenders of local contractors and on data collected during work visits to project sites.

Costs and prices were estimated in euros or in US dollars. Neither was extrapolated, but their linear 10 year trends were used in sensitivity analysis, for estimating possible changes in model assumptions.

Of the 14 projects analyzed in this study, six projects were developed for various regions of Russia, six for other CIS countries, and two for EE countries. All the projects relate to agricultural production and to storage/processing/packaging. 
Processing agricultural raw materials included analysis of the following stages: production of pig and poultry meat products, production of feed mixes in livestock farms, production at soybean processing plants, oil extraction from plant material, long-term storage of fruit in controlled atmosphere, and egg product production. The average cost of investment in 3 projects based on crops (fruit, vegetable greenhouses, and plantation and oil extraction) was 4.6 million US \$. For a soy processing project, which requires the construction of an oil extraction plant, other production units, and storage bins for raw material, 74 million US \$was invested, and for 10 projects based on livestock production the average investment was 59 million US \$ (Table 2).

Technological characteristics of the projects are shown in Table 3, and compared to the countries' average or typical values. These comparisons change in various industries; the greatest difference is in the vegetable greenhouse industry, and close to zero differences are shown in the soy industry, broilers, and the egg industry in Russia and Belarus. In contrast, in the same egg industry in Romania the difference is essential. The table footnotes include a list of data sources used for comparing the projects' characteristics to the countries' average or typical values. In Table 3, most projects show high vertical integration.

\section{Using spreadsheet models for business planning}

For evaluation purposes, a spreadsheet business plan model was developed for each project. Production was detailed by biological/technological phases. For an integrated poultry meat farm, for example, these phases could include rearing the parent flock, breeding, hatchery, brooding and fattening commercial chicks, slaughtering and meat processing. Feed expenses for livestock farms were described in a separate module. Weekly step models were used for the poultry farms, and monthly step models for other livestock farms and crop industries. Cash flow was forecast based on output from production and sales modules. These flows included modules of income and expenses, along with production, investment, and financing cash flows. The planning horizon was assumed as the sum of the initial development period plus additional 5 years of production activity. For plantations, a longer planning horizon was used.

The models allowed for the calculation of all economic indices used in project evaluation:

- Variable and fixed costs per unit of product;

- Operating profit;

- Degree of operating leverage; and

- The variety of economic performance measures as they relate to nominal and discounted cash flows, current earnings and investment.

Using equations derived from herd and flock movement (in terms of weeks and months) and from plantation/greenhouse productivity (in terms of months and years) enabled sensitivity analysis of project profitability, based on spreadsheet formulae. For various industries, the following parameters of sensitivity were used: production prices in farm gate value; production volume; total production costs, production costs of feed 
Table 3 Technological characteristics and vertical integration of the projects

\begin{tabular}{|c|c|c|c|c|c|c|}
\hline \multirow[t]{2}{*}{ № } & \multirow{2}{*}{$\begin{array}{l}\text { Project, country, } \\
\text { Federal District }\end{array}$} & \multicolumn{4}{|c|}{ Major technological characteristic } & \multirow[t]{2}{*}{ Vertical integration } \\
\hline & & Value & Unit & $\begin{array}{l}\text { Compared to } \\
\text { country's value }\end{array}$ & $\begin{array}{l}\text { Data source for } \\
\text { the comparison }\end{array}$ & \\
\hline 1 & Eggs, Russia, Central & 308 & Eggs/layer/year (lay rate) & $101 \%$ & A & Parents flock, hatchery, feed mill \\
\hline 2 & Turkeys, Russia, Privolzhsky & 2.62 & Feed Consumption Ratio & $61 \%$ & B & Parents flock, hatchery, feed mill \\
\hline 3 & Fruit, Azerbaijan & 38.3 & Apple ton/ha & $432 \%$ & C & Pack-house, fruit long storage in controlled atmosphere \\
\hline 4 & Vegetable greenhouses, Azerbaijan & 485 & Tomato ton/ha/year & $513 \%$ & $D, E$ & Growing seedlings, packaging production \\
\hline 5 & Broilers, Russia, Privolzhsky & 2.0 & Feed Consumption Ratio & $98 \%$ & $\mathrm{~F}$ & Parents flock, hatchery, feed mill \\
\hline 6 & Broilers, Kazakhstan & 2.0 & Feed Consumption Ratio & $98 \%$ & $\mathrm{~F}$ & Parents flock, hatchery, feed mill \\
\hline 7 & Eggs, Romania & 308 & Lay rate & $224 \%$ & G & Parents flock, hatchery, feed mill, manure pelleting plant \\
\hline 8 & Orchard+extraction & 537 & Kg of tea tree oil/hectare & $363 \%$ & $\mathrm{H}$ & Plantation, oil extraction plant \\
\hline 9 & Pig farm, Belarus & 3.23 & Feed Consumption Ratio & $77 \%$ & I & Main herd, feed mill, meat products plant \\
\hline 10 & Turkeys, Russia, Central & 2.39 & Feed Consumption Ratio & $56 \%$ & B & Hatchery, feed mill, meat products plant \\
\hline 11 & Turkeys, Belarus & 2.62 & Feed Consumption Ratio & $61 \%$ & B & Parents flock, hatchery, feed mill, meat products plant \\
\hline 12 & Soy, Russia, Far East & $16 \%$ & Oil yield & $102 \%$ & J & Seed storage, soy processing, bottling line, feed mill \\
\hline 13 & Eggs, Belarus & 308 & Lay rate & $102 \%$ & K & Parents flock, hatchery, feed mill, egg melange plant \\
\hline 14 & Milk farm, Russia, North-West & 11 & Ton of milk per cow/year & $262 \%$ & A & Main herd, feed center, biogas plant \\
\hline
\end{tabular}

A) Russia's average in 2008-2010, for agricultural enterprises (RosStat 2012).

B) Turkey of Stavropol region (2012). Recommendations of this breeding center, the largest in Russia, are taken as a base for comparison for projects both in Russia and Belarus.

C) FAOSTAT (2012), yield in Azerbaijan, 2008-2010: 8.87 ton/ha.

D) FAOSTAT (2012), yield in Azerbaijan, 2008-2010: 17.1 ton/ha in open field. Data for greenhouse are not available for Azerbaijan.

E) Moghaddam et al. (2011), report of tomato yield in greenhouse 5.52 times higher than in open field in Iran with similar climatic conditions. Comparing the projected yield 485 ton to the open field yield in Israel (81 ton/ha (2008-2010) - FAOSTAT 2012) gives the close ratio 5.99.

F) Kochish et al. (2010). In this study, FCR for 5 breeding crosses of broilers raised in different production systems in one of the Russian large industrial farms are calculated. They belong to the range [1.9, 2.2] when the average FCR equals 2.03. G) Calculated by data from FAOSTAT (2012), 2008-2010. Includes estimates both for enterprises and individual (less productive) farms.

H) Chudleigh and Simpson (2010). The base scenario in this evaluation of investment assumes the yield $148 \mathrm{~kg}$ oil of tea tree per hectare.

1) Chudleigh and Simpson (2010). The base scenario in this evaluation of investment assumes the yield $148 \mathrm{~kg}$ oil of tea tree per hectare.

I) Resolution 568 of the Belanus Govents 4.2 for pigs in Belarus (2009). the project. The oil yield in this extraction plant equals $15.7 \%$ (2010).

K) The agro-industrial association Belptizeprom, http://www.agrobel.by/ru/node/23258 (in Russian). The lay rate in industrial poultry farmsin Belarus reached 303 in 2009. Additional data are available from the author on request. 
and genetic materials; oil content; fruit and vegetable yields; productivity; and animal survival rate.

To cope with uncertainty in assumptions and data, the following scenarios were used in business planning and cash flow forecasting:

- Changes in farm integration. E.g.: a) the parent flock against purchasing eggs for a hatchery; b) construction of a meat processing plant and sale of meat products against the sale of chickens and savings in the investment in the plant;

c) construction of feed mill against purchasing feed mixes.

- Decisions to move to the next phase of the investment. E.g.: investment in capacities for deep-processed products in a soy plant.

- Changes in financing terms and institutional environment. E.g.: changes in interest, loan repayment and grace periods offered by banks; discounts in taxes and customs; and price subsidies.

The spreadsheet bio-economic model for business planning enables a simulation of economic output from changing biological input. The case of an integrated turkey farm was described by Yom Din et al. (2010). In this study, the changing parameters of bird survival rate, egg hatchability, carcass to live animal weight ratio, and eggs layer productivity were used to simulate the internal rate of return for the enterprise.

\section{Project evaluation and ranking}

During the evaluation phase of a project, a business plan has to be prepared for consideration by decision makers. If the project is to participate in a tender held under the auspices of a regional government in Russia, it has to meet the conditions defined by government Decree 1470 (1997). The plan also must be consistent with criteria from the investing bank. In Russia, this may be Rosselkhozbank, the largest bank working in the agricultural sector, which published its "Toolkit for Developing a Project Business Plan" in 2007. The financial section of a business plan must include a forecast of economic indicators for the company which will be established in order to implement the project.

In government and bank documents, the recommended criteria for project performance and return on investment are given. For example in 2005, the government of Belarus released Decision 158, which proposed four criteria to evaluate investment project efficiency. These efficiency criteria were based on cash flows (usually, discounted): net income, return on investment, internal rate of return, and payback period.

The Russian government, in the above-mentioned Decree 1470, recommended a payback period along with two other possible criteria:

- A discounted cash flow that takes into account governmental subsidies for the project, along with income and other taxes that the company will pay from earnings (the budget effect of the project);

- A break-even point, where a decline in production leads to zero profits. 
In CIS countries, the following criteria are common and are used in this study to evaluate the 14 projects under analysis.

a) The criterion of return on investment (ROI) is defined as the operating profit, divided by the cost of investment. For the purposes of this study, the operating profit was calculated as earnings before interest and taxes (EBIT) - the difference between revenue and expense from the normal agro-industrial project activities, not including the effects of interest and taxes. The performance criterion: projects with a high ROI are preferable.

b) The criterion of payback period (PP) is defined as the period of time, in years, required to recover the project investment cost according to the net cash flow (NCF) - as in this study - or discounted NCF. The criterion: projects with a shorter PP are preferable.

c) Internal rate of return (IRR) is the rate of discount that turns the accumulated NCF of the project into zero. The criterion: projects with a higher IRR are preferable. The first two criteria are based on an accounting approach, in which the same importance is given to NCF values obtained at different times. The third criterion is based on an economic approach, in which NCF values receive different weights at different times (discounting). For sectors of agriculture that have a slow initial establishment period for biological reasons - for example the time it takes to establish a herd, or initial growth on a plantation - the assessment period can last up to 7 years or more.

d) To evaluate sensitivity of profit to risk, the following index was used: the sensitivity of project profit, as a percentage, to the simultaneous deterioration of the basic production and market parameters by one percent (see the next section for details). The criterion: projects with lower sensitivity are preferred.

Decision-makers attach varying importance to the project evaluation criteria discussed above. To examine the consistency of project evaluation as calculated by different criteria, the following method was used: all of the analyzed projects were ranked by each of the relevant four criteria. Then the first three sequences of ranks (the performance criteria ROI, PP, IRR) were examined for internal consistency using Cronbach's alpha index. This statistical index (Cronbach 1951) is widely used, in particular to examine project performance consistency (Khang and Moe 2008). In addition, for each sequence of rank pairs, the significance of the correlation coefficient was estimated.

The value of Cronbach's alpha and the significance of the correlation coefficients enabled a conclusion on performance criteria consistency to be drawn. Finally, the significance of correlation coefficients between ranking by performance measures and by profit sensitivity to risk was estimated.

\section{Profit sensitivity to risk in the cost-volume-profit model}

The cost-volume-profit model is based on the following assumptions:

- Agro-industrial enterprise produces and sells a single product (this restriction will be removed later); 
- Income and expenses are represented by linear functions of model parameters;

- These parameters - variable and fixed costs, product price - are known, non-random values.

This widely used economic tool is analyzed in the economic literature (Magee 1975; Guidry et al. 1998). In addition to the analysis of management decisions and their financial implications, the opportunity to evaluate profit sensitivity to changes in model parameters is of importance (Kee 2007).

Operational profit $P$ of an enterprise ('project profit') is defined as follows:

$$
P=(S P-V C) \cdot Q-F C,
$$

where $S P$ is a price of a unit of production,

$V C$ is variable costs per unit of production,

$F C$ is fixed costs of the enterprise, and

$Q$ is sales volume.

A relative change (sensitivity) of profit $P$ is noted as $R_{P}=\frac{\Delta P}{P}$, where $\Delta P$ is a small change in profit. Similarly, a relative change of sales volume is noted as $R_{Q}$, of prices as $R_{S P}$, of variable costs as $R_{V C}$, and of fixed costs as $R_{F C}$.

The following formula for relative change in profit under simultaneous change in the four model parameters was derived by Milanovic et al. (2010):

$$
R_{P}=\frac{S P \cdot Q}{P} \cdot\left(R_{S P}+R_{Q}+R_{S P} \cdot R_{Q}\right)-\frac{V C \cdot Q}{P} \cdot\left(R_{V C}+R_{Q}+R_{V C} \cdot R_{Q}\right)-\frac{F C}{P} \cdot R_{F C} .
$$

In the special case when all model production and market parameters deteriorate by one percent (such deterioration is called "risk" in this article):

$$
R_{S P}=R_{Q}=-1 \%, R_{V C}=R_{F C}=1 \%,
$$

the approximate formula can be written as follows:

$$
\begin{aligned}
R_{P} & =\frac{S P \cdot Q}{P} \cdot(-0.01-0.01+0.01 \cdot 0.01)-\frac{V C \cdot Q}{P} \cdot(0.01-0.01-0.01 \cdot 0.01)-\frac{F C}{P} \cdot 0.01 \approx \\
& \approx\left(-\frac{S P-V C}{P} Q+\frac{-S P \cdot Q-V C \cdot Q-F C}{P}\right) \cdot 0.01= \\
& =\left(-\frac{S P-V C}{P} Q+\frac{(S P-V C) Q-F C}{P}-\frac{2 S P \cdot Q}{P}\right) \%
\end{aligned}
$$

The expression $\frac{S P-V C}{P} Q$ is the degree of operational leverage $D O L$, which shows the relative variation in operational profit when sales volume changes by one percent. The $D O L$ is a measure of enterprise business risk (McDaniel 1984). The expression $P /(S P \cdot \mid, Q$ ) shows profitability to sales, and is noted $P_{\%}$. 
Finally, the following expression of profit sensitivity to risk is obtained:

$$
R_{P}=\left(1-2 / P_{\%}-D O L\right) \% \text {. }
$$

That is, when cost-volume-profit model parameters deteriorate by one percent, the higher the degree of operating leverage, the higher is decrease in profit, and the higher the profitability, the smaller is decrease in profit.

In the case of $n$ products, the following formula (Milanovic et al. 2010) is used:

$$
R_{P}=\sum_{i=1}^{n}\left(\frac{S P_{i} \cdot Q_{i}}{P} \cdot\left(R_{S P_{i}}+R_{Q_{i}}+R_{S P_{i}} \cdot R_{Q_{i}}\right)-\frac{V C_{i} \cdot Q_{i}}{P} \cdot\left(R_{V C_{i}}+R_{Q_{i}}+R_{V C_{i}} \cdot R_{Q_{i}}\right)\right)-\frac{F C}{P} \cdot R_{F C}
$$

and in a similar way, the approximate formula for profit sensitivity to risk is obtained as follows:

$$
R_{P}=\frac{n}{100}-\sum_{i=1}^{n}\left(2 / P_{\% i}+D O L_{i}\right) \%
$$

For every product $i$, the degree of operating leverage and profitability have the same meaning as in the formula for a single product.

Using the formula (1), elasticity of profit sensitivity to risk is calculated as follows:

$$
\begin{aligned}
& \varepsilon_{R_{P} / P_{\%}}=\frac{2}{100 P_{\%} \cdot R_{P}} \text { for elasticity to profitability, } \\
& \varepsilon_{R_{P} / D O L}=-\frac{P_{\%}}{100 R_{P}} \text { for elasticity to the degree of operational leverage, }
\end{aligned}
$$

and for the ratio between them:

$$
\varepsilon_{R_{P} / P_{\%}} / \varepsilon_{R_{P} / D O L}=-2 / P_{\%}^{2} .
$$

Thus, for projects with reasonable profitability - less than $140 \%$ as it follows from (5) - elasticity to profitability is greater in absolute value than elasticity to the degree of operating leverage.

\section{Results}

The degree of operating leverage (DOL) and its calculation data are presented in Table 4, with the projects listed in ascending order of DOL. Projects based on crop production are at the bottom of the table, reflecting the high proportion of fixed costs in greenhouses, extraction plants, and perennial plant plantation enterprises. In contrast, an Azerbaijani fruit project is in first place due to the minimal DOL. This project is characterized by a high proportion of variable costs stemming from 
Table 4 Project financial indices in ascending order of degree of operational leverage

\begin{tabular}{|c|c|c|c|c|c|c|c|c|}
\hline № & Project & Unit & Quantity & Price, $\$$ & Variable costs, US\$/unit & $\begin{array}{l}\text { Fixed costs, } \\
\text { US\$ million }\end{array}$ & $\begin{array}{l}\text { Operating profit, } \\
\text { US\$ million }\end{array}$ & $\begin{array}{l}\text { Degree of operating } \\
\text { leverage }\end{array}$ \\
\hline 3 & Fruit, Azerbaijan & ton & 2,080 & 1,058 & 196 & 0.3 & 1.5 & 1.17 \\
\hline \multirow[t]{4}{*}{12} & Soy, Russia, Far East FD & & & & & & & \\
\hline & oil & ton & 18,240 & 1,172 & 761 & & & \\
\hline & proteins & ton & 54,380 & 1,470 & 955 & & & \\
\hline & Total project & & & & & 6.0 & 29.5 & 1.20 \\
\hline 10 & Turkeys, Russia, Central FD & & & & & & & \\
\hline
\end{tabular}

10 Turkeys, Russia, Central FD

$\begin{array}{lllll}\text { Meat } & \text { ton } & 4,578 & 4,090 & 1,332 \\ \begin{array}{l}\text { Meat products } \\ \text { Total project }\end{array} & \text { ton } & 5,174 & 8,165 & 1,708 \\ \text { Pig farm, Belarus } & \text { ton } & 2,751 & 5,432 & 540 \\ \begin{array}{l}\text { Turkeys, Russia, Privolzhsky FD } \\ \text { Broilers, Russia, Privolzhsky FD }\end{array} & \text { ton } & 13,062 & 5,120 & 1,466 \\ \text { Eggs, Belarus } & \text { ton } & 21,939 & 2,698 & 1,106 \\ \text { Eggs } & & & & \\ \text { Melange } & \text { thous. eggs } & 233,000 & 78 & 46 \\ \text { Tot } & \text { ton } & 1,800 & 1,553 & 869\end{array}$

Total project

Turkeys, Belarus

Meat

Meat products

Total project

Eggs, Romania

Broilers, Kazakhstan

4 Vegetable greenhouses, Azerbaijan

$\begin{array}{llll}\text { ton } & 3,129 & 4,168 & 1,216 \\ \text { ton } & 6,068 & 6,100 & 1,527 \\ & & & \\ \text { thous. eggs } & 257,000 & 97.0 & 44.9 \\ \text { ton } & 15,031 & 3,277 & 1,424 \\ \text { ton } & 2,500 & 1,240 & 80\end{array}$

ton

80

$\begin{array}{lll}11.2 & 34.9 & 1.32 \\ 3.5 & 10.0 & 1.35 \\ 12.5 & 35.2 & 1.36 \\ 9.6 & 25.3 & 1.38 \\ & & \\ & & \\ 2.4 & 6.3 & 1.39 \\ & & \\ & & \\ 10.5 & & 1.40 \\ 4.0 & 26.5 & 1.43 \\ 9.7 & 9.4 & 1.53 \\ 1.0 & 18.2 & 1.54\end{array}$


Table 4 Project financial indices in ascending order of degree of operational leverage (Continued)

\begin{tabular}{|c|c|c|c|c|c|c|c|c|}
\hline 8 & Orchard + extraction & ton & 68 & 22,500 & 515 & 0.6 & 0.9 & 1.65 \\
\hline \multirow[t]{4}{*}{14} & Milk farm, Russia, North-West FD & & & & & & & \\
\hline & Milk & ton & 22,000 & 500 & 136 & & & \\
\hline & Cattle & ton & 540 & 4,150 & 645 & & & \\
\hline & Total project & & & & & 4.3 & 5.6 & 1.78 \\
\hline 1 & Eggs, Russia, Central FD & thous. eggs & 397,000 & 61.7 & 36.4 & 6.1 & 4.0 & 2.51 \\
\hline
\end{tabular}


laboratory fruit analysis, long-term storage requirements in a controlled atmosphere, electronic sorting of fruit to determine quality, and packaging requirements for wholesale and retail trade. The high DOL found in project number 1 (eggs) is due to the low profit of the poultry farm under consideration, which operated near the breakeven point. This was caused by lower prices for eggs in Russia until the mid-2000s, while prices increased for resources consumed by this industry over the same period.

The projects were ranked based on profitability data (Table 5) using the procedure described above. Cronbach's alpha index was calculated on the three columns of this table related to performance measures, which received a high value of 0.821 . Usually, in economic studies an alpha value of more than 0.7 is considered acceptable to reach a conclusion on internal consistency, which in our case is ranking projects by different measures. Thus it can be concluded that the project evaluation on the basis of the chosen performance measures is consistent (Table 6).

Analysis of correlation coefficients calculated for each of the three possible pairs of ranks lead to a similar conclusion. This analysis revealed the high significance of the correlation coefficients ( $1 \%-5 \%)$.

At the same time, the correlation coefficients between each ranking by performance criteria and ranking by profit sensitivity are close to zero (Table 7).

Values of elasticity of profit sensitivity to risk were calculated for every project using formulae (3) and (4). They returned the following values: elasticity to profitability from $0.83-0.97 \%$ and elasticity to DOL from $0.01-0.23 \%$. The projects estimated profitability ranged from $16-70 \%$ (Table 5). For every project, the ratio between elasticity values to profitability and to DOL was much greater than unity (Table 8). This means that in terms of elasticity, profit sensitivity to risk was influenced by the project profitability to a much greater degree than by DOL, in accordance with the remark after (5).

Table 5 Project profitability: the profitability measures calculated for the studied projects

\begin{tabular}{llllll}
\hline No & Project, country, Federal District & $\begin{array}{l}\text { Return on } \\
\text { investment }\end{array}$ & IRR & $\begin{array}{l}\text { Payback } \\
\text { period, years }\end{array}$ & $\begin{array}{l}\text { Profitability } \\
\text { to sales }\end{array}$ \\
\hline 1 & Eggs, Russia, Central & $6.2 \%$ & $3.0 \%$ & 12.5 & $16 \%$ \\
2 & Turkeys, Russia, Privolzhsky & $27.1 \%$ & $26.2 \%$ & 3.7 & $53 \%$ \\
3 & Fruit, Azerbaijan & $18.7 \%$ & $19.8 \%$ & 9.3 & $70 \%$ \\
4 & Vegetable greenhouses, Azerbaijan & $17.2 \%$ & $26.6 \%$ & 4.3 & $61 \%$ \\
5 & Broilers, Russia, Privolzhsky & $20.5 \%$ & $23.5 \%$ & 4.5 & $43 \%$ \\
6 & Broilers, Kazakhstan & $22.1 \%$ & $30.0 \%$ & 4.8 & $37 \%$ \\
7 & Eggs, Romania & $21.9 \%$ & $32.1 \%$ & 3.5 & $38 \%$ \\
8 & Orchard + extraction & $38.3 \%$ & $24.0 \%$ & 8.0 & $59 \%$ \\
9 & Pig farm, Belarus & $19.8 \%$ & $26.6 \%$ & 7.5 & $67 \%$ \\
10 & Turkeys, Russia, Central & $19.6 \%$ & $27.5 \%$ & 5.3 & $57 \%$ \\
11 & Turkeys, Belarus & $18.9 \%$ & $26.6 \%$ & 7.2 & $53 \%$ \\
12 & Soy, Russia, Far East & $26.82 \%$ & $39 \%$ & 4.0 & $29 \%$ \\
13 & Eggs, Belarus & $21.1 \%$ & $20.6 \%$ & 6.0 & $30 \%$ \\
14 & Milk farm, Russia, North-West & $13.0 \%$ & $8.5 \%$ & 9.0 & $32 \%$ \\
\hline
\end{tabular}


Table 6 Project ranking by performance measures and profit sensitivity to risk

\begin{tabular}{|c|c|c|c|c|c|}
\hline \multirow[t]{2}{*}{ № } & \multirow[t]{2}{*}{ Project } & \multicolumn{3}{|c|}{ Measures of performance* } & \multirow[b]{2}{*}{$\begin{array}{l}\text { Profit } \\
\text { sensitivity }\end{array}$} \\
\hline & & $\begin{array}{l}\text { Return on } \\
\text { investment }\end{array}$ & IRR & Payback period & \\
\hline 1 & Eggs, Russia, Central FD & 14 & 14 & 14 & 14 \\
\hline 2 & Turkeys, Russia, Privolzhsky FD & 2 & 8 & 2 & 6 \\
\hline 3 & Fruit, Azerbaijan & 10 & 12 & 13 & 1 \\
\hline 4 & Vegetable greenhouses, Azerbaijan & 12 & 6 & 4 & 4 \\
\hline 5 & Broilers, Russia, Privolzhsky FD & 7 & 10 & 5 & 8 \\
\hline 6 & Broilers, Kazakhstan & 4 & 3 & 6 & 10 \\
\hline 7 & Eggs, Romania & 5 & 2 & 1 & 9 \\
\hline 8 & Orchard + extraction & 1 & 9 & 11 & 5 \\
\hline 9 & Pig farm, Belarus & 8 & 7 & 10 & 2 \\
\hline 10 & Turkeys, Russia, Central FD & 9 & 4 & 7 & 3 \\
\hline 11 & Turkeys, Belarus & 4 & 3 & 6 & 10 \\
\hline 12 & Soy, Russia, Far East FD & 3 & 1 & 3 & 12 \\
\hline 13 & Eggs, Belarus & 6 & 11 & 8 & 11 \\
\hline 14 & Milk farm, Russia, North-West FD & 13 & 13 & 12 & 13 \\
\hline
\end{tabular}

\section{Discussion}

The agro-industrial project market in the CIS and EE countries studied is favorable for companies and developers. In terms of investment, the volume for the five largest countries (Russia, Ukraine, Belarus, Kazakhstan, and Romania) comes close to US \$18 billion per annum. The upward trend in prices for crop and livestock production continues in the last years. The high proportion of food expenditure in the household budget, the growing demand for food, and the potential for a substantial increase in food exports indicate that it is very likely that the present demand for agro-industrial projects will not decrease in the near future. The projects are supported by regional and central governments by subsidies of interest on bank loans, reduced taxes, and subsidies for less profitable enterprises (milk, eggs). A high degree of vertical integration and use of the latest technological solutions contribute to the success of the projects analyzed.

Project evaluation by various performance measures is a prerequisite for success in this market. For the projects studied, different performance criteria have been shown to provide ranking consistency. This is a good basis for successful integration of the results, which is important for several decision-makers. The economic literature offers various methods for the integration of investment project evaluations by different performance criteria (Chong 2008; Subramanian and Ramanathan 2012).

Table 7 Correlation coefficients between ranking by performance measures and by profit sensitivity to risk

\begin{tabular}{lllll}
\hline & Return on investment & IRR & Payback period & Profit sensitivity \\
\hline Return on investment & 1 & & & \\
IRR & $0.54^{*}$ & 1 & & \\
Payback period & $0.53^{*}$ & $0.74^{* *}$ & 1 & 1 \\
Profit sensitivity & 0.04 & 0.07 & -0.02 & 1 \\
\hline
\end{tabular}

* Significance at $5 \%$.

** Significance at $1 \%$. 
Table 8 Elasticity calculation of profit sensitivity to risk

\begin{tabular}{|c|c|c|c|c|c|c|}
\hline № & Project, country, Federal District & $\begin{array}{l}P_{\%} \text { - profitability to sales, } \\
\text { from Table } 5\end{array}$ & $\begin{array}{l}D O L \text { - degree of operating } \\
\text { leverage, from Table } 4\end{array}$ & $\begin{array}{l}R_{P}-\text { profit sensitivity to risk, } \\
\text { from equation ( } 2 \text { ) }\end{array}$ & $\begin{array}{l}\text { Elasticity to profitability, } \\
\text { from equation ( } 3 \text { ) }\end{array}$ & $\begin{array}{l}\text { Elasticity to } D O L, \\
\text { from equation (4) }\end{array}$ \\
\hline 1 & Eggs, Russia, Central & $16 \%$ & 2.51 & $-13.75 \%$ & $-0.89 \%$ & $0.01 \%$ \\
\hline 2 & Turkeys, Russia, Privolzhsky & $53 \%$ & 1.36 & $-4.16 \%$ & $-0.91 \%$ & $0.13 \%$ \\
\hline 3 & Fruit, Azerbaijan & $70 \%$ & 1.17 & $-3.03 \%$ & $-0.95 \%$ & $0.23 \%$ \\
\hline 4 & Vegetable greenhouses, Azerbaijan & $61 \%$ & 1.54 & $-3.84 \%$ & $-0.86 \%$ & $0.16 \%$ \\
\hline 5 & Broilers, Russia, Privolzhsky & $43 \%$ & 1.38 & $-5.06 \%$ & $-0.92 \%$ & $0.08 \%$ \\
\hline 6 & Broilers, Kazakhstan & $37 \%$ & 1.53 & $-5.95 \%$ & $-0.91 \%$ & $0.06 \%$ \\
\hline 7 & Eggs, Romania & $38 \%$ & 1.43 & $-5.75 \%$ & $-0.93 \%$ & $0.07 \%$ \\
\hline 8 & Orchard + extraction & $59 \%$ & 1.65 & $-4.04 \%$ & $-0.84 \%$ & $0.15 \%$ \\
\hline 9 & Pig farm, Belarus & $67 \%$ & 1.35 & $-3.34 \%$ & $-0.90 \%$ & $0.20 \%$ \\
\hline 10 & Turkeys, Russia, Central & $57 \%$ & 1.32 & $-3.82 \%$ & $-0.92 \%$ & $0.15 \%$ \\
\hline 11 & Turkeys, Belarus & $53 \%$ & 1.40 & $-4.18 \%$ & $-0.90 \%$ & $0.13 \%$ \\
\hline 12 & Soy, Russia, Far East & $29 \%$ & 1.20 & $-7.07 \%$ & $-0.97 \%$ & $0.04 \%$ \\
\hline 13 & Eggs, Belarus & $30 \%$ & 1.39 & $-7.07 \%$ & $-0.95 \%$ & $0.04 \%$ \\
\hline 14 & Milk farm, Russia, North-West & $32 \%$ & 1.78 & $-7.44 \%$ & $-0.83 \%$ & $0.04 \%$ \\
\hline
\end{tabular}


Market changes and different levels of integration have been taken into account when comparing projects from the same industry for different years. For instance, for projects 2 (2006) and 10 (2011), both in the turkey industry, investment for the latter project is greater at $29 \%$ (Table 2), though production volume is lower $(23 \%)$ and the additional cost of the meat products plant (Table 3) accounts for only $4 \%$ of the total investment. This increased investment is caused by the rise in construction costs and equipment in Russia in the period 2006-2011, and explains low indices of return on investment and payback period for project. At the same time, most of the sales for this more integrated project come from meat products, which are more profitable than the chilled meat that made up a large part of the sales volume from project 2 . This explains why profitability and internal profitability (IRR) are somewhat higher in project 10.

In the projects studied no correlation between their ranking by performance criteria and by profit sensitivity to risk was shown. For example, the Azerbaijani fruit enterprise was ranked first in low profit sensitivity to risk. This project employed long-term fruit storage technology and was characterized by a high proportion of variable costs and by a long period between the initial investment to a full commercial crop. The first feature explains the low degree of operating leverage and, given the high operating profitability (70\%), the low profit sensitivity to risk. The second feature lead to a negative cash flow during the first $4-5$ years of the project. This leads accordingly to low IRR and a long payback period (Table 6). This example illustrates a possible scenario for agroindustrial projects in which ranking by performance evaluation can be inconsistent with ranking by profit sensitivity to risk evaluation.

Profit sensitivity to risk for the surveyed projects is high, with changes from $3-14 \%$ in response to a simultaneous one percent deterioration of production and market parameters (Table 8). However, the risk of parameter deterioration can be lower than that of traditional agriculture due to the industrial nature of the technology used, significant amount of storage capacity for raw materials, large sales volume from products processed from raw materials, ability to create financial reserves, and the ongoing analysis of animal condition and of raw materials and product quality. The projects where the main technological characteristics are close to the host country's typical values, and do not show significant advantages from this criterion (projects 1, 5, 6, 12, 13 in Table 3) are the most sensitive projects, with ranks ranging from $8-14$ (Table 6).

\section{Conclusions}

From the perspective of the agro-industrial projects developers, the market in the studied countries of the CIS and EE is large and varies by region and industry. The market is favorable to developers due to external (world price growth) and internal (positive changes in the institutional environment due to food security concerns) factors. The decision-makers in this market - the region, the bank, and the initiator - use different evaluation criteria.

A method for project evaluation using the criterion of profit sensitivity to risk is proposed. The approximate formulas for profit sensitivity to risk (when basic production and market assumptions change simultaneously) and its elasticity are derived, based on the cost-volume-profit model. The formulae enable reduced calculations to explain profit sensitivity and elasticity using the usual indicators of business planning: operational profitability and degree of operating leverage. 
In order to examine the project ranking consistency by different criteria, Cronbach's alpha and correlation coefficients were used. For the studied projects, their ranks by performance measures are consistent with each other, but are not correlated with their ranking by profit sensitivity to risk. The positive result from this inconsistency is that evaluating projects by profit sensitivity to risk may provide useful, additional information to decision-makers.

The main limitation of the derived approximate formulae for profit sensitivity to risk analysis is found in the assumption that the used cost-volume-profit model is linear to its four main parameters. Analysis with the removal of this assumption is an area for future research.

Competing interests

The authors declares that he has no competing interests.

\section{Acknowledgements}

The author gratefully acknowledges experts and colleagues from the following Israeli companies: AgriGo, Agro Technology, AgroTop, as well as agronomists Ilan Sela, Dror Dagan, Dr. Zinaida Zugman, and Professor Roman Sheinberger for their professional advice and insight in the preparation of this article.

Received: 3 September 2012 Accepted: 26 March 2013

Published: 15 May 2013

\section{References}

BelStat (2012) National Statistical Committee of the Republic of Belarus. http://www.belstat.gov.by/homep/en/main. html. Accessed 19 Mar 2013

Ben-Zion U, Zolotoy L, Yom Din G (2005) Skewness Aversion, Output Uncertainty and Hedging in a Futures Market. Available via SSRN: http://ssrn.com/abstract=673344 Accessed 19 Mar 2013

Berkowitz D, DeJong D (2011) Growth in post-soviet Russia: a tale of two transitions. J Econ Behav Organ 79(1-2):133-143 Bevzeluk A (2008) Metodi ocenki investicionnykh proektov. Bankajski vesnik 19(lipen):12-18, (Банкаўскі веснік 19 (ліпень)). In Russian

Bojnec Š, Fertő I (2012) Does EU enlargement increase agro-food export duration? World Econ 35:609-631

Chien Yl, Cunningham WHJ (2000) Incorporating production planning in business planning: a linked spreadsheet approach. Prod Plan Control 11(3):299-307

Chudleigh P, Simpson S (2010) Economic Evaluation of Investment in the Tea Tree Oil R\&D Program. RIRDC Publication No 10/212: ISBN 978-1-74254-177-8, ISSN 1440-6845

Chong G (2008) How to Appraise Investment Projects. J Corp Accounting \& Finance 19(2):59-64

Commodity Markets (2012) The World Bank. http://www.worldbank.org/prospects/commodities. Accessed 19 Mar 2013

Cronbach LJ (1951) Coefficient Alpha and the Internal Structure of Tests. Psychometrika 16:297-334

EuroStat (2012a) Consumption expenditure of private households. http://epp.eurostat.ec.europa.eu/portal/page/portal/ eurostat/home. Accessed 19 Mar 2013

EuroStat (2012b) National Accounts. http://epp.eurostat.ec.europa.eu/portal/page/portal/national_accounts/data/ database. Accessed 19 Mar 2013

FAOSTAT (2012) Data collection of the Statistics Division of the Food and Agriculture Organization of the United Nations. http://faostat.fao.org/. Accessed 19 Mar 2013

Goldman MI (2003) The piratization of Russia: Russian reform goes awry. Routledge, London

Guidry F, Horrigan JO, Craycraft C (1998) CVP analysis: a new look. J Managerial Issues 10(1):74-85

Hockmann H, Gataulina E, Hahlbrock K (2011) Risk, technical efficiency and market transaction costs in different organizational forms: evidence from the oblast Tatarstan. No 114510, 51st Annual Conference, Halle, Germany, German Association of Agricultural Economists (GEWISOLA). http://ageconsearch.umn.edu/bitstream/114510/2/ Hockmann_et_al.pdf. Accessed 19 Mar 2013

Isakov IY (2011) Application of the state financial institutions of development for activization of investment process. Polythematic power electronic scientific journal of the Kuban State Agrarian University, №67(67) (in Russian), http://ej.kubagro.ru/2011/03/pdf/14.pdf. Accessed 15 April 2013

Kalugina ZI (2011) Vector of postcrisis development of rural Russia. Regional Research of Russia 1(2):149-156 KazStat (2012) Statistics Agency of the Republic of Kazakhstan. http://stat.kz/Pages/default.aspx. Accessed 19 Mar 2013

Kee R (2007) Cost-volume-profit analysis incorporating the cost of capital. J Managerial Issues 19(4):478-493

Khang DB, Moe TL (2008) Success criteria and factors for international development projects: a lifecycle based framework. Project Management J 39(1):72-84

Kochish I, Fedkina T, Kovinko V (2010) Genotype, environment and broilers' performance. Animal Husbandry of Russia 9:11-12 (in Russian). http://zzr.ru/archives/2010/09/09-2010 02.pdf. Accessed 19 Mar 2013

Ksenofontov MY, Gromova NA, Polzikov DA (2012) Forecast-analytical studies on the priorities of agrifood policy. Studies on Russian Economic Development 23(2):115-127

Kuehne G, Nicholson C, Robertson M, Llewellyn R, McDonald C (2012) Engaging project proponents in R\&D evaluation using bio-economic and socio-economic tools. Agricultural Systems, 108:94-103. http://www.sciencedirect.com/ science/article/pii/S0308521X1200025X. Accessed 14 Apr 2013 
Liefert WM, Liefert O (2012) Russian agriculture during transition: performance, global impact, and outlook. Applied Economic Perspectives and Policy 34(1):37-75

Lioubimtseva E, Henebry GM (2012) Grain production trends in Russia, Ukraine and Kazakhstan: new opportunities in an increasingly unstable world? Frontiers of Earth Science 6(2):157-166

Magee RP (1975) Cost-volume-profit analysis, uncertainty and capital market equilibrium. J Accounting Res 13(2):257-266

Mansurov PE (2011) Kriterii ocenki konkurentosposobnosti agropromishlennogo predpriyatiya. Vestnik Rossiyskoy Akademii selskohozyaystvennyh nauk 3:22-24 (in Russian). http://elibrary.ru/contents.asp?issueid=937344\&selid= 16378021. Accessed 19 Mar 2013

McDaniel WR (1984) Operating leverage and operating risk. J Bus Finance \& Accounting 11:113-125

Milanovic D, Lj MDD, Misita M, Klarin M, Zunjic A (2010) Universal equation for the relative change in profit of manufacturing company. Prod Plan Control 21(8):751-759

Moghaddam PR, Feizi H, Mondani F (2011) Evaluation of tomato production systems in terms of energy use efficiency and economical analysis in Iran. Not Sci Biol 3(4):58-65

Otiman PI (2012) Romania's present agrarian structure: a great (and Unsolved) social and economic problem of our country. Agr Econ \& Rural Development 9(1):3-24

Parfenova EN (2009) Problemi metodiki ocenki regionalnykh investicionnykh proektov. Nauchnye vedomosti BelGU. Ser History, Politology, Economics 12(1):22-27 (in Russian)

Petrick M, Wandel J, Karsten K (2012) Economic \& social impacts of recent agro-investment in Kazakhstan's grain region. In: Annual World Bank Conference on Land and Poverty. http://www.landandpoverty.com/agenda/pdfs/paper/ petrick_full_paper.pdf. Accessed 19 Mar 2013

Romania Stat (2012) National Institute of Statistics, Romania. http://www.insse.ro/cms/rw/pages/index.en.do. Accessed 19 Mar 2013

RosStat (2012) Federal State Statistics Service. http://www.gks.ru/wps/wcm/connect/rosstat/rosstatsite/main/. Accessed 19 Mar 2013

Saubanov KR (2010) Konkurentosposobnost regionalnogo selskogo khozyaistva vprivolzhskom federalnom okruge: otsenka i puti povisheniya. PhD thesis (in Russian). http://www.dissercat.com/content/konkurentosposobnostregionalnogo-selskogo-khozyaistva-v-privolzhskom-federalnom-okruge-otse. Accessed 15 April 2013

Sauer J, Gorton M, White J (2012) Marketing, cooperatives and price heterogeneity: evidence from the CIS dairy sector. Agr Econ 43(2):165-177

Shepotylo O (2012) Export diversification across countries and products: do Eastern European (EE) and Commonwealth of Independent States (CIS) countries diversify enough? I Int Trade \& Econ Development 21:1-34

The State Program for Development of Agriculture and Regulation of Agricultural Commodities Markets in 2013-2020 (2012) The Ministry of Agriculture of the Russian Federation (in Russian). http://government.ru/gov/results/19885/. Accessed 19 Mar 2013

Strashko IV (2010) Business-planirovanie investicionnykh proektov v APK: conceptualnyj podhod. Problemi sovremennoy ekonomiki 1(33):414-417 (in Russian)

Subramanian N, Ramanathan R (2012) A review of applications of analytic hierarchy process in operations management. Int J Prod Econ 138(2):215-241

Torok A, Jambor A (2012) Changes in agri-food trade of the new member states since EU accession - a quantitative approach. http://ideas.repec.org/p/ags/iaae12/125140.html. Accessed 19 Mar 2013

Turkey of Stavropol region (2012) Selective Breeding Genetic Center. http://indeikastav.ru/en/incubation12.html. Accessed 19 Mar 2013

UkrStat (2012) State Statistics Service of Ukraine. http://ukrstat.gov.ua/. Accessed 19 Mar 2013

Vasina NV (2012) Modelirovanie finansovogo sostoyaniya selskohozyajstvennih organizacij pri ozenke ih kreditosposobnosti., ISBN 978-5-98566-078-4, Omsk (in Russian)

Visser O, Mamanova N, Spoor M (2012) Oligarchs, mega-farms and land reserves: understanding land grabbing in Russia. J Peasant Stud 39(3-4):899-931

Voicilas DM (2011) Investment process in Romania and institutional dysfunctionalities. J Eur Stud \& International Relations 14(2):359-370

Voigt P, Hockmann H (2008) Russia's transition process in the light of a rising economy: economic trajectories in Russia's industry and agriculture. Eur J Comparative Econ 5(2):179-195

Wandel J, Pieniadz A, Glauben T (2011) What is success and what is failure of transition? A critical review of two decades of agricultural reform in the Europe and Central Asia region. Post-Communist Econ 23(2):139-162

Wegren SK (2012) Institutional impact and agricultural change in Russia. J Eurasian Studies 3(2):193-202

Wise TA, Murphy S (2012) Resolving the Food Crisis: Assessing Global Policy Reforms Since 2007. Institute for Agriculture and Trade Policy, Global Development and Environmental Institute. http://iatp.org/documents/ resolving-the-food-crisis-assessing-global-policy-reforms-since-2007. Accessed 19 Mar 2013

Yom Din G, Gilad S, Zugman Z (2010) A model for estimating how variability of biological parameters affects economic factors in an integrated turkey farm. Comput Electron Agr 75(1):100-106

Zaharov AN (2006) O perspektivakh razvitiya rossijskogo APK (in Russian). http://ecsocman.hse.ru/data/535/626/1219/ zaxarov.pdf. Accessed 19 Mar 2013

Zhang W, Wilhelm WE (2011) OR/MS decision support models for the specialty crops industry: a literature review. Ann Oper Res 190(1):131-148

doi:10.1186/2193-7532-1-3

Cite this article as: Yom Din: Performance and profit sensitivity to risk: a practical evaluation of the agroindustrial projects developed by Israeli companies for the CIS and Eastern European countries. Agricultural and Food Economics 2013 x1:xx3. 